\title{
MIR371A Gene
}

National Cancer Institute

\section{Source}

National Cancer Institute. MIR371A Gene. NCI Thesaurus. Code C158710.

This gene may play a role in tumor malignancy. 